\title{
Cuando las lapas se fueron de Cartago
}

\author{
María Martha Durán Rodríguez*
}

\section{RESUMEN}

Hace 300 años, el 4 de julio de 1710, soldados españoles mataron en Cartago a Presbere, el Pa Blu de Suinsi, Talamanca, el Rey de las Lapas. Muchas personas han contribuído a la construcción y consolidación de la identidad costarricense. El Cacique Presbere es una de ellas. Su cruel muerte nos recuerda que luchó por la libertad, respeto e identidad de nuestros pueblos originarios, teniendo la unidad como clave de su accionar. Este ensayo es un homenaje a un hombre que hizo historia en Costa Rica y que no debe ser olvidado. Se hace un breve recuento de la historia de Presbere, ubicando su contexto histórico.

Palabras clave: Indígenas, Colonización, Talamanca, Presbere, rebelión, lapas

\section{ABSTRACT}

When the macaws left Cartago. 300 years ago, on the 4th of July 1710, in Cartago, Spanish soldiers murdered Presbere, the "Pa Blu" of "Suinsi", Talamanca, the Macaw King. Many people have contributed to the construction and consolidation of the Costa Rican identity. The chief Presbere is one of them. His cruel death reminds us that he fought for the freedom, respect and identity of our indigenous peoples, being "Unity" a key to his actions. This essay is a tribute to his memory, in which a brief recount of the history is made, explaining the historical context and the main events (that occurred).

Key words: Indigenous, Colonization, Talamanca, Presbere, rebellion, macaw.

* Psicóloga graduada en la Universidad de Costa Rica, con posgrado en Psicología del Trabajo y las Organizaciones de la misma universidad y cursos especializados en Gestión de Personal realizados en Alemania.

Docente universitaria durante 17 años en la Universidad de Costa Rica, actualmente labora como profesional en la Escuela de Ciencias de la Administración de la Universidad Estatal a Distancia. También es docente en la UNED en la Maestría de Administración de Negocios y en la Cátedra de Estrategia Empresarial. 


\section{"Héroe"}

(Fragmento)

El traslado de los aborígenes

a Buenos Aires

trajo muerte y desgracia,

la voz de la alarma despertó

a toda la comarca.

Los blancos llegaban con armas

que vomitaban fuego,

y mataban de lejos

mujeres, hombres,

niños y viejos.

Los indígenas aprendieron

que su libertad se había ido

que ya no podrían vivir

como su pasado idilio.

En esos momentos

surge de la selva Pablo Presbere

$y$ en su pecho palpitando,

un corazón rebelde,

a su pueblo defendería,

aunque le costara la muerte.

Pablo con gran valentía

organizaba a su pueblo

porque pasara lo que pasara,

a su gran Talamanca

no acabarían.

El 4 de julio de 1710

Pablo Presbere fue ejecutado

muriendo por el pueblo

con gran heroísmo

$y$ sin temor demostrado.

Jorge Luis Jiménez Vargas

12 años

II Lugar Premio Letra Joven, 2003

Centro Costarricense de La Ciencia y La Cultura
Hace 300 años, el 4 de julio de 1710, soldados españoles mataron en Cartago a Presbere, el Pa Blu de Suinsi, Talamanca.

Hasta 1561 los intentos de dominación española, en lo que hoy es Costa Rica, se concentraron en la región de la costa del Caribe y en la península de Nicoya. A finales del siglo XVI, los españoles lograron establecer un núcleo de colonización en la región del Valle Central, en el interior del país. Desde aquí lanzaron expediciones con el fin de capturar indígenas en las llanuras del norte y para dominar los territorios del sur ocupados por los "indios bravos" en la región de Talamanca (Molina y Palmer, 2004), impulsados especialmente por la veloz caída demográfica y necesidad de mano de obra para emplearla en las explotaciones agropecuarias de los españoles en el Valle Central, además de la competencia entre el Estado y la Iglesia Católica por expoliar al máximo a los aborígenes. Sin embargo, los españoles tuvieron que hacer frente a la constante rebelión indígena $(1610,1613,1620,1662$, $1699 \ldots$..), a pesar de los esfuerzos organizados en Cartago para sofocar la resistencia.

A finales del siglo XVII, una nueva ofensiva dirigida por los frailes franciscanos trató nuevamente de someter las poblaciones indígenas de Talamanca, mediante el uso de la 
fuerza y la política de despoblamiento y desarraigo recomendada por ellos y adoptada por la corona española. El resultado fue el estallido de una nueva sublevación en 1709 , dirigida por los líderes indígenas Presbere y Comesala. Presbere logró, mediante el convencimiento, unificar a casi todas las tribus de la Gran Talamanca para detener el avance de la conquista en sus territorios. Así se inició uno de los capítulos más violentos de la colonia que significó para nuestros indígenas un éxito en tanto se puso freno a la expansión hispánica en este territorio.

\section{Antecedentes}

Y llegaron ellos, los otros, las armas, sedientos de oro, de tierras, de almas. Dividieron pueblos familias y cuerpos. Con la sangre ajena sus leyes marcaron.

\section{Ani Brenes Herrera (2005). Se llamaba Pablo. Fragmento.}

Durante la época de colonización de Costa Rica la necesidad de mano de obra para la explotación de los yacimientos auríferos era condición necesaria para obtener financiamiento que garantizara su expansión en el interior del país; aunado a esto, el surgimiento y multiplicación de las haciendas cacaoteras de Matina, convirtió a la población indígena en elemento clave para el desarrollo y fortalecimiento de ese proceso.

Desde la perspectiva de los indígenas, la dominación española y el establecimiento de poblaciones mediante el traslado forzado a áreas controladas por los españoles, las acciones de estos como la captura de caciques y saqueo de cultivos, la sobre-explotación como mano de obra en condiciones de cuasi esclavitud, la miseria, el sometimiento a castigos crueles y tortura por cualquier pretexto, las violaciones de la servidumbre indígena femenina y tantos otros abusos, provocaron una alteración del orden social tradicional y trastornaron la concepción de su orden cósmico, situación que sólo desaparecería con la expulsión de los españoles.

En este contexto, la religión tradicional ocupó un papel primordial en el territorio de Talamanca. Por medio de revelaciones proféticas, los chamanes lograron concertar la acción unificada de las diversas etnias indígenas que habitaban esa región, divididas por conflictos interétnicos que facilitaron la incursión e implantación de los españoles. Los indígenas establecieron alianzas y formaron confederaciones para enfrentar a los invasores españoles, y sus triunfos fortalecieron la confianza en sus posibilidades para enfrentarlos.

De esa forma, los indígenas de Talamanca se convirtieron en una fuerza permanente de resistencia, 
capaz de influir en lo social y lo religioso en los territorios vecinos sometidos a las instituciones políticas y económicas coloniales. Talamanca fue una fuente de apoyo moral y de reforzamiento ideológico de los jefes religiosos indígenas, quienes contribuyeron de manera decisiva a mantener el espíritu rebelde entre las poblaciones sometidas al yugo colonial, concentrándose aquí el mayor número de indígenas del país.

Ante esta situación los españoles intentaron dominar no sólo por la fuerza de las armas, sino también mediante la evangelización de los indígenas, como forma de contrarrestar el poder ideológico y religioso de los chamanes indígenas, además de que los misioneros tenían intenciones de despoblar Talamanca y trasladar sus habitantes hacia el Valle Central y el valle de Diquís. Así lograrían reprimir a la población indígena sublevada, además de mitigar la escasez de mano de obra en Cartago.

\section{Ataque indígena}

Como consecuencia de la presión constante de los españoles, tanto de soldados como de misioneros, los indígenas de Talamanca organizaron una nueva rebelión generalizada que se concretó a inicios del siglo dieciocho. Así se pondría fin al avance misional iniciado en las últimas décadas del siglo diecisiete.
En setiembre de 1709, bajo la dirección de los jefes indígenas Comesala y Pablo Presbere, un numeroso grupo de guerreros indígenas atacó sorpresivamente a los españoles (Solórzano, 1996). Durante el ataque, los centros misioneros de Cabécar, Urinama y Chirripó fueron destruidos.

Ambos líderes indígenas concentraron sus fuerzas en Suinsi, sin despertar la sospecha de los españoles. De aquí se dirigieron con un grupo de guerreros indígenas cabécares y terbis hacia el poblado de San Bartolomé de Urinama, donde se encontraba fray Pablo de Rebullida, al que atacaron sorpresivamente. En el ataque pereció este fraile y dos soldados que le acompañaban.

Luego, el jefe Comesala, con un grupo de indígenas, dieron muerte a fray Antonio de Zamora, a dos soldados, la mujer y el hijo de uno de ellos. Posteriormente, el día 28 de setiembre, una fuerza numerosa de indígenas procedentes de varios pueblos, armados de lanzas de pejibaye y broqueles, atacaron el pueblo cabécar de San Juan donde se encontraba fray Antonio de Andrade en compañía del grueso de la tropa española. Cinco soldados murieron en el enfrentamiento, huyendo el resto de españoles a Cartago.

Una vez que los españoles se retiraron, los indígenas dieron fuego a catorce iglesias fundadas por los misioneros, los conventos y las casas de cabildo, destruyendo además 
algunas de las imágenes y objetos sagrados, siendo algunos repartidos entre los jefes participantes. Además, se exhumaron los cadáveres de indígenas para ser sepultados según sus costumbres, evidenciando así la carga ideológico religiosa del enfrentamiento (Solórzano, op.cit).

\section{Respuesta española}

El gobernador de Costa Rica preparó una gran expedición militar con la ayuda de la Audiencia de Guatemala.

A principios de 1710 se disponía ya en Cartago de un arsenal adecuado y de financiamiento para dirigir hacia Talamanca una considerable tropa de soldados. Se preparó un plan destinado a atacar Talamanca por dos frentes: una fuerza compuesta por ochenta soldados salió directamente con rumbo a Talamanca por el camino de Chirripó; otro grupo formado por el gobernador y el fraile Antonio de Andrade se dirigió hacia el pueblo de Boruca a la cabeza de 120 soldados.

En Cabécar los españoles establecieron su cuartel general emprendiendo numerosos ataques en las tierras de los indígenas rebeldes, logrando capturar a unos 700 indígenas, incluído el jefe indígena Presbere. No obstante, el Cacique Comesala $\mathrm{y}$ otros indígenas lograron escapar escondiéndose en las escarpadas montañas de la zona.
Después de permanecer varios meses en las montañas de Talamanca, en junio los españoles emprendieron el regreso hacia Cartago, alegando no poder permanecer más en la región por "la fragosidad de las montañas y entrada del invierno" (Colección de Documentos para la Historia de Costa Rica, tomo IX, p. 108. Citado por Solórzano, 1997:173).

En el camino hacia Cartago, perecieron y huyeron alrededor de 200 indígenas, llegando unos 500. Tal como lo había ofrecido el gobernador, estos indígenas fueron repartidos entre los expedicionarios a fin de que los emplearan para su servicio personal (no hay duda que estos indígenas fueron tratados duramente pues nueve años más tarde de los 500 indígenas traídos quedaban, según testimonio del gobernador Haya Fernández (Citado por Solórzano, op.cit:1997:174).

Después de la sublevación indígena y de la represión española, los frailes iniciaron gestiones para reanudar las misiones en Talamanca pero toparon con la negativa del obispo de Nicaragua, además del interés en Costa Rica de que la evangelización la llevasen a cabo los jesuitas, por lo que también hubo oposición a los proyectos de los franciscanos recoletos. Así quedó demostrado que los españoles sólo podrían controlar la región si mantenían una numerosa tropa de soldados en este territorio, lo que no estaban en condiciones de financiar. 
Fue así como Talamanca quedó nuevamente al margen de la colonización hispánica.

Para los indígenas, a pesar de la fuerte represión y captura de varios centenares de los integrantes de sus comunidades, la rebelión fue un éxito pues en adelante los españoles no pudieron emplearlos más y lograron mantener a Talamanca como zona donde prevaleció la soberanía de los autóctonos hasta finales de la colonia.

\section{Pa Blu Presbere}

\section{Se llamaba Pablo}

el cacique fuerte, indómito y bravo.

Desde las alturas del Chirripó alto

su grito de guerra se fue deslizando,

lleno de espacios de cada comarca cargado de fuerza, de orgullo de savia.

"Esta tierra es nuestra", lloró la montaña.

"Esta tierra es nuestra", gritaron la danta, el árbol, el río, el sol y la rana en la voz de Pablo y su Talamanca a los invasores en cruenta batalla.

Ani Brenes Herrera (2005). Se llamaba Pablo. Fragmento.

1669 fue el año aproximado de nacimiento de Presbere, quien fue Cacique de Suinsi en Talamanca, sitio ubicado en la margen derecha del río Coén y a unos cinco kilómetros al este de San José Cabécar.
$\mathrm{Su}$ nombre fue Pa Blu (o Bru como se consigna en algunos escritos). "Pa" significa Lapa en bribrí, mientras que "Blu" jefe o cacique (Borge, s.f; Gonzáles, 2002), de esta forma "Pa Blu" es "Jefe o Cacique de las Lapas" y fue castellanizado como "Pablo". Bozzoli y otros investigadores (1983:54, citado por González, op.cit) propusieron un posible significado para Presbere o Presberi: "Pres podría derivar de un lugar de aguas salobres; bere, bri o beri se refiere a los caños por donde corre el agua en invierno... de tal modo que Presbere vendría de una quebrada u hondonada cercana al Río Suinsi”.

Presbere no fue un guerrero, a pesar de que así aparezca en la documentación y de ser el líder de una revuelta armada. Lo más probable es que su actividad como líder estuviese asociada con rituales mágicos y no con la guerra (Barrantes, citado por Solórzano 1996: 141; 1997: 170).

Como lo consignaron los propios frailes, antes de 1706 cuando los misioneros entraron con soldados armados, Presbere había rehusado el bautismo y había mostrado una gran oposición a los misioneros. Si al final aceptó el bautizo con el nombre de Pablo, se debió probablemente a la amenaza representada por la fuerza militar. Según este investigador (op. cit.), su oposición al bautizo y a la labor misional de los frailes derivaba probablemente de su función como chamán de los bribris. De ahí que disponía del poder de desatar las fuerzas 
mágicas y por medio de estas convocar y dirigir la rebelión que imponían las circunstancias a los indígenas.

De los caciques Comesala y Presbere, este último era el más importante en tanto que poseedor de las facultades psíquicas especiales de los chamanes, capaces de ejercer influencia sobre el curso de los acontecimientos. Sobre Comesala es poco lo que las fuentes indican. Era cabécar y cacique en el poblado que los frailes llamaron Santo Domingo. Pedro Comesala sobrevivió para reorganizar la nación de Talamanca y continuar su defensa.

El Cacique Presbere fue hecho prisionero por los españoles y se le siguió juicio en Cartago. En el juicio mostró una gran entereza moral y fortaleza en sus principios al negarse a responder y acusar a sus compañeros. El $1^{\circ}$ de julio de 1710 fue condenado: sería exhibido por toda la ciudad en la que se pregonaría su delito, moriría arcabuceado y su cabeza cortada sería puesta en lo alto de un palo para que todos la vieran y sirviese de escarmiento a todos los indígenas de esta provincia y que los vecinos apreciaran "el peso de la ley cuando se trataba de insurrección" (Esquivel, 1996).

La ejecución se realizó en la Plaza Mayor de Cartago el 4 de julio de 1710.

La terrible muerte de Pablo Presbere no fue la primera ni la última que se aplicó en la capital colonial de
Costa Rica. Esta sentencia "acostumbrada" durante en esta época y a la que fueron sometidos otros líderes de pueblos originarios de América Latina (Tupac Amaru es otro ejemplo), refleja el uso de los españoles del terror como medio de represión y control. Además, convirtió al Pa Blu en un héroe para sus tribus, carácter que hoy se extiende a todo nuestro país por el valor en la defensa de los territorios que los conquistadores solo supieron ganar con el ejercicio de la fuerza y no de la convivencia pacífica.

Tatiana Lobo, en su bellísima novela histórica Asalto al Paraíso relata que cientos de lapas aparecieron en Cartago cuando los prisioneros indígenas llegaron a la capital colonial. Se ubicaron en el campanario del Convento de La Soledad, donde tenían preso a Presbere. De muchas maneras los pobladores trataron de ahuyentarlas pero no lo consiguieron.

El 4 de julio las lapas volaron hacia el oeste... "acompañan al sol. El sol lleva el alma de Presbere prendida de sus rayos, hacia el mundo más abajo, donde lo espera la inmortalidad ...(y)... donde sería recibido con todos los honores del guerrero muerto en batalla" (Lobo 1992: 314-315).

Desde entonces, no hay lapas en Cartago.

El 19 de marzo de 1997 la Asamblea Legislativa declara a Pablo Presbere "Defensor de la Libertad de los Pueblos Originarios" 


\section{Bibliografía}

Barrantes, Claudio (1985). Los caminos de Presbere en la Época Colonial. En: Relación de actividades. Comisión Nacional de Nomenclatura. San José: Ministerio de Cultura, Juventud y Deportes.

Borge Carvajal, Carlos (1994). Talamanca en la Encrucijada. San José: Editorial Universidad Estatal a Distancia.

Brenes Herrera, Ani (2005). Al maestro con cariño. San José: Editorial FUNCODESUP

Fernández Esquivel, Franco (1996). La Plaza Mayor. Génesis de la Nación Costarricense. Cartago: Uruk Editores.

Fernández Esquivel, Franco (2008). Crónicas $y$ tradiciones de Cartago. Cartago: Uruk Editores.

González Vásquez, Fernando (2002). Tatiana Lobo: artifice de la palabra. En Revista Comunicación, vol. 12. Cartago: Institu- to Tecnológico de Costa Rica. Accesible en http://redalyc.uaemex.mx/redalyc/ pdf/166/16609824.pdf

Lobo, Tatiana (1992). Asalto al Paraíso. San José: Editorial Universidad de Costa Rica.

Molina, Iván; Palmer, Steven (2004). Historia de Costa Rica. Segunda edición. San José: Editorial Universidad de Costa Rica.

Solórzano Fonseca, Juan Carlos (1996). Rebeliones y sublevaciones de los indigenas contra la dominación española en las áreas periféricas de Costa Rica (de 1502 a 1710). En Anuario de Estudios Centroamericanos, Vol 22 (1), págs. 125-147. San José: Editorial Universidad de Costa Rica.

Solórzano Fonseca, Juan Carlos (1997). Indígenas insumisos, frailes y soldados: Talamanca y Guatuso, 1660 - 1821. En Anuario de Estudios Centroamericanos, Vol 23 (1-2), págs 143-197. San José: Editorial Universidad de Costa Rica. 